\title{
Satellite Climate Data Records: Development, Applications, and Societal Benefits
}

\author{
Wenze Yang ${ }^{1, *,+}$, Viju O. John ${ }^{2,+}$, Xuepeng Zhao ${ }^{3,+}$, Hui Lu ${ }^{4,5,+}$ and Kenneth R. Knapp ${ }^{3,+}$ \\ 1 Cooperative Institute for Climate and Satellites-Maryland, Earth System Science Interdisciplinary Center, \\ University of Maryland, College Park, MD 20740, USA \\ 2 EUMETSAT, 64295 Darmstadt, Germany; Viju.John@eumetsat.int \\ 3 National Centers for Environmental Information, Asheville, NC 28801, USA; \\ Xuepeng.Zhao@noaa.gov (X.Z.); Ken.Knapp@noaa.gov (K.R.K.) \\ 4 Ministry of Education Key Laboratory for Earth System Modeling, Center for Earth System Science, \\ Tsinghua University, Beijing 100084, China; luhui@tsinghua.edu.cn \\ 5 Joint Center for Global Change Studies, Beijing 100875, China \\ * Correspondence: ywze98@umd.edu; Tel.: +1-301-405-6568; Fax: +1-301-405-8468 \\ + These authors contributed equally to this work.
}

Academic Editors: Jiaguo Qi, Richard Müller and Prasad S. Thenkabail

Received: 15 February 2016; Accepted: 6 April 2016; Published: 15 April 2016

\begin{abstract}
This review paper discusses how to develop, produce, sustain, and serve satellite climate data records (CDRs) in the context of transitioning research to operation (R2O). Requirements and critical procedures of producing various CDRs, including Fundamental CDRs (FCDRs), Thematic CDRs (TCDRs), Interim CDRs (ICDRs), and climate information records (CIRs) are discussed in detail, including radiance/reflectance and the essential climate variables (ECVs) of land, ocean, and atmosphere. Major international CDR initiatives, programs, and projects are summarized. Societal benefits of CDRs in various user sectors, including Agriculture, Forestry, Fisheries, Energy, Heath, Water, Transportation, and Tourism are also briefly discussed. The challenges and opportunities for CDR development, production and service are also addressed. It is essential to maintain credible CDR products by allowing free access to products and keeping the production process transparent by making source code and documentation available with the dataset.
\end{abstract}

Keywords: climate data record; satellite; remote sensing

\section{Introduction}

Due to rapid advances in the past half-century in climate observations, especially satellite observations from passive and active sensors of both geostationary and polar-orbiting satellites, climate observations are transitioning from the practice of individual, regional, and short-term observations to multiple, global, and long-term observations. Thus, long-term consistent Earth satellite observations_called climate data records (CDRs)—are becoming indispensable for providing information for improved detection, attribution, and prediction of global climate and environmental changes. They also help decision makers and society respond and adapt to climate change and variability in a resilient fashion [1-3]. The National Research Council of the U.S. National Academy of Science recommended the development of CDRs from environmental satellites in its 2004 and 2008 review reports $[4,5]$. This review paper for the Special Issue of satellite climate data records and applications will provide a general overview of the development, production, and service of long-term satellite CDRs along with their application in the study of climate and environment changes covered in the literature. Opportunities and challenges for the CDR research and user communities will also be discussed. 


\section{CDRs and Development}

A climate data record (CDR) is defined as a time series of measurements of sufficient length, consistency, and continuity to determine climate variability and change [4]. A Climate Information Record (CIR) is a time series derived from CDRs along with related in-situ and/or model data that provide specific information to address a specific climate application.

Satellite observations have been used to produce CDRs due to their global coverage and sufficient length of temporal coverage. In practical terms, this amounts to transforming satellite sensor data records (SDR) across decades from multiple satellite platforms into uninterrupted and coherent long-term SDR through re-calibration and reprocessing. The time series of inter-calibrated SDRs for a family of sensors together with the ancillary data used to calibrate them is a fundamental climate data record (FCDR). Then, a geophysical parameter (e.g., sea ice, clouds, etc.) is derived from a FCDR, which creates a thematic CDR (TCDR) often by blending satellite observations with in-situ data and model output.

Considering that there are users who require regular access to CDR data with low latency (e.g., daily or monthly updates) rather than a fully mature CDR product, an interim climate data record (ICDR) can be produced. This is accomplished by forward processing the CDR algorithm using near-real time observations. While this decreases the maturity of the CDR (by not having the retrospective calibration), the ICDR can be improved after the fact through retrospective calibration and reprocessing. Figure 1 shows the production pathways schematically for various CDR products (ICDR, FCDR, TCDR, and CIR) and their relative dependence, which is produced in either shortly-delayed or delayed fashions (compared to near-real time production) to meet the needs from different users. More details on the development and production of various types of CDR products in a sustainable way are provided in the following subsections.

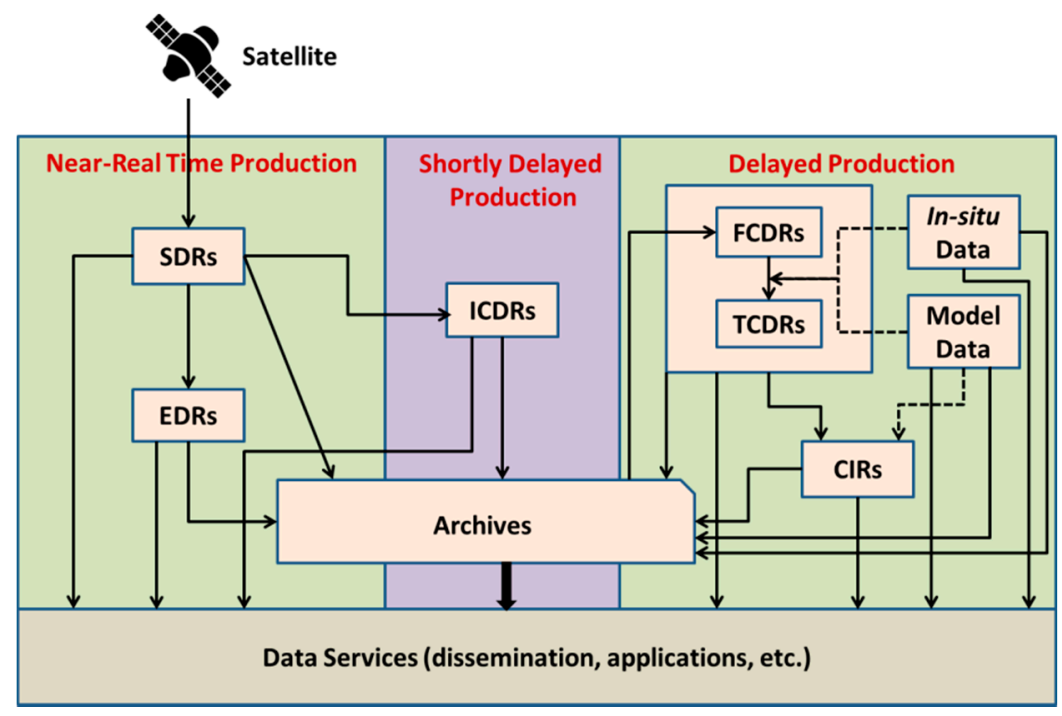

Figure 1. Schematic diagram of production pathways for various climate data record (CDR) products (ICDR - interim CDR, FCDR—-fundamental CDR, TCDR - thematic CDR, and CIR—climate information record) and their relative dependence along with their relationship with near-real time products: Sensor Data Records (SDRs) and Environmental Data Records (EDRs). Dash lines indicate optional paths.

\subsection{Calibration and FCDR}

The cross- and inter-satellite calibration along with reprocessing is critical for the generation of all the FCDRs, since observations from multiple satellite platforms need to be smoothly and seamlessly stitched together to form a long-term homogenized record [6]. Current satellite instruments generally 
have more advanced on-board calibration technology, which leads to better calibration accuracy and precision, so they are used to retrospectively calibrate their predecessor instruments $[7,8]$.

Aside from the on-board calibration, vicarious calibration is normally needed to characterize the current satellite instrument performance and bring their radiometric measurements to climate quality before being used to cross- and inter-calibrate with legacy satellite instruments. Both artificial and natural sites, such as the under-orbit airplanes, deserts, ice domes, deep convective clouds (DCC), and the Moon [9-15] have been used for the post-launch vicarious calibration of satellite sensors. This vicarious calibration and on-board calibration strive to match the satellite radiometric measurements to the international standards (SI) [16-18].

Reprocessing inter- and cross-calibrated satellite radiometric measurements using Sensor Data Record (SDR) production schemes will bring the SDRs to climate quality FCDRs. FCDRs are generally produced for orbital swath since they are mainly used as the inputs for the follow-on production of TCDRs. However, some FCDRs are produced by merging and mapping several observations into a defined grid to enhance its spatial and temporal coverage and resolution, such as the Geostationary Gridded Satellite (GridSat) IR Channel Brightness Temperature FCDR [19].

\subsection{Retrieval and $T C D R$}

Retrieval algorithms developed for Environmental Data Record (EDR) production from SDR are normally used to produce TCDR from FCDR through reprocessing. The algorithms are usually updated through intensive validation to meet certain maturity criteria, such as those defined in Bates and Privette [20]. TCDRs are generally produced for Essential Climate Variables (ECVs) for land, ocean, and atmosphere, as defined by the Global Climate Observing System (GCOS) [2,3]. The specifications given by GCOS for ECV data products are designed to provide information to characterize the state of the global climate system and enable long-term monitoring, which are considered most valuable to climate researches as a long-term dataset.

The retrieval algorithms developed for the current and future satellite observations are inevitably more sophisticated than that of legacy instruments, thus, seamlessly stitching the past, current, and future satellite observations together to produce long-term TCDRs is a challenge. Bias correction used for generating satellite TCDR products by using in-situ measurements or another climate-quality satellite observation [21-23] may help to effectively homogenize TCDRs produced from the algorithms developed differently for the past, current, and future instruments. Unified enterprise algorithms [24,25] applicable to multiple sensors with different designs can be also a feasible solution.

\subsection{Value-Added ICDR and CIR}

The succession of satellites, with different designs and changing performance qualities, makes combining all past and current observations into a consistent long-term record a major challenge. In order to homogenize the satellite measurements across decades and multiple platforms, all the knowledge captured about the sensor characteristics, calibration, and performance must be applied retrospectively through reprocessing, which can be a time consuming task. Thus, the production and delivery of CDRs may not be able to meet the needs of the users who have requirements for near-real time or shortly delayed products. Considering that such users are more concerned with data timeliness than the maturity of the product, an ICDR can be produced by forward processing with the near-real time observations without retrospective calibration and cross-platform homogenization. This ICDR can be later re-processed to improve it to the full CDR maturity.

For tailored use of CDRs in various user sectors (such as agriculture, fishery, forestry, energy, health, water, transportation, tourism, etc.), CIRs are derived from CDRs to provide authoritative climate reference datasets for use by decision makers to devise strategies to respond and adapt to, as well as mitigate climate change impacts and trends. For example, various climate and environmental indices/indicators (or CIRs) have been developed by combining satellite CDRs with related in-situ 
and/or model data in the extreme context [26-28], which have significant economic and societal implications [29].

To produce a suite of CDRs (FCDR, TCDR, ICDR, and CIR) for sustaining climate information (see Figure 1) as well as serve the diverse needs of users (including academy, industry, government, and the general public), an architecture for CDR development and production is critical, such as the one illustrated in Bates et al. [3]. This architecture should be defined and developed using a systems engineering methodology that considers requirements definition, design, implementation, test, sustained operation and maintenance, and periodic improvements. At the same time, the development and production of a CDR requires the collaboration between experts in the climate community and experts in data management. The process is also informed by scientific application and associated user feedback on the accessibility and usability of the CDRs. Figure 2 provides a practical example of end-to-end production chain from FCDR through CIR. The Advanced Very High Resolution Radiometer (AVHRR) Pathfinder Atmospheres-Extended (PATMOS-x) reflectance FCDR at the top of the atmosphere (TOA) was derived from cross- and inter-satellite calibrations $[7,30]$ and used to generate the cloud fraction CDR [31,32]. Then, both AVHRR PATMOS-x reflectance FCDR and cloud fraction CDR were used to produce the aerosol optical thickness (AOT) TCDR [33], from which a CIR of long-term AOT trend was derived [34].

a) AVHRR Ch-1 Reflectance (FCDR); Sept. 2009

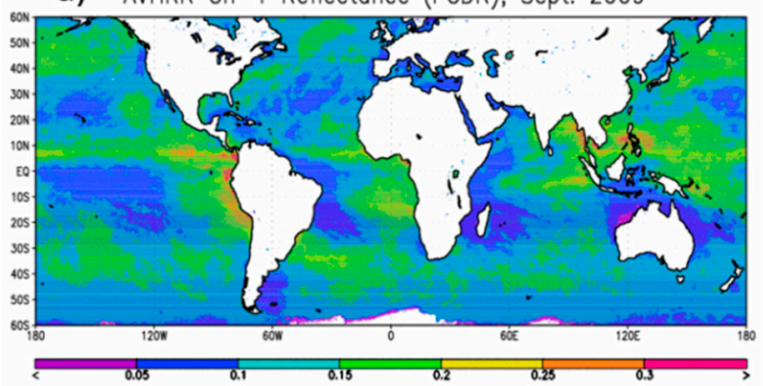

c) AVHRR AOT (TCDR); Sept. 2009

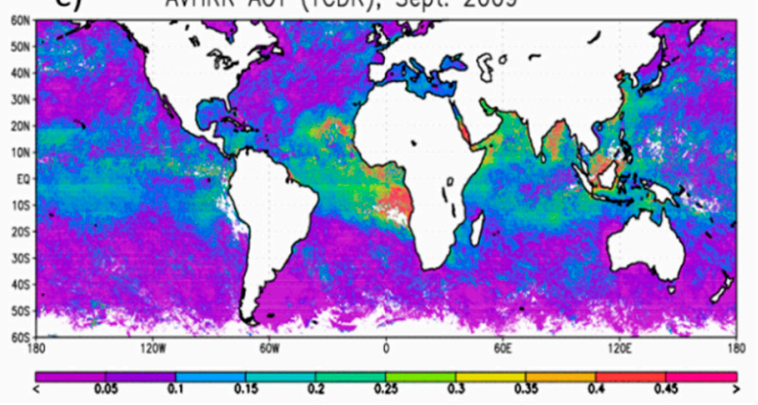

b) AVHRR Cloud Froction (CDR); Sept. 2009

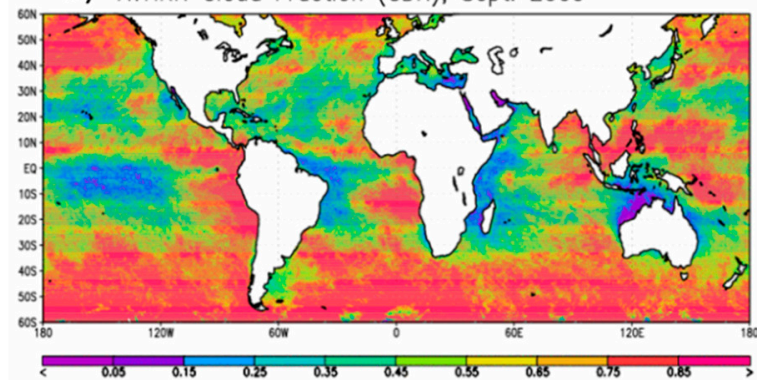

d)

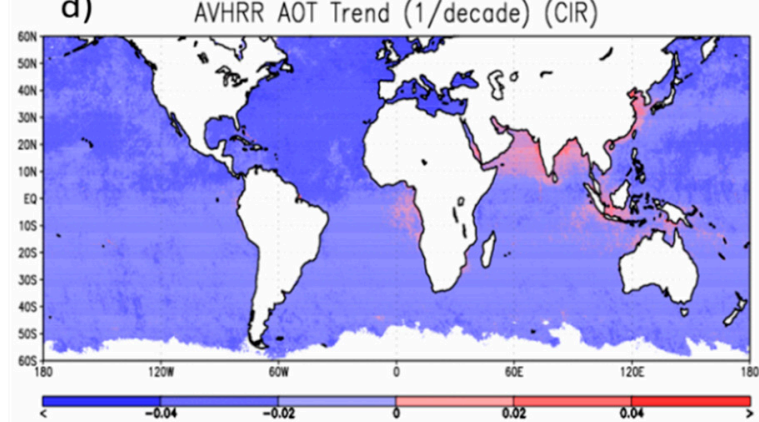

Figure 2. An example of a climate data record (CDR) production chain: (a) Fundamental CDR (AVHRR reflectance at $0.63 \mu \mathrm{m}$ channel); (b) CDR (AVHRR cloud fraction); (c) Thematic CDR (AVHRR aerosol optical thickness (AOT)); and (d) Climate Information Record (AVHRR AOT trend).

\subsection{International Coordination}

The CEOS/CGMS Working Group on Climate (WGClimate [35]) was established in 2010 and is a joint group including Committee on Earth Observation Satellite (CEOS) Agencies and the Coordination Group for Meteorological Satellite (CGMS). The WGClimate coordinates and encourages collaborative activities between the world's major space agencies in the area of climate monitoring with the overarching goal to improve the systematic availability of Climate Data Records through the coordinated implementation and further development of a global architecture for climate monitoring from space. WGClimate facilitates the implementation and exploitation of ECV time-series through coordination of the existing and substantial activities undertaken by CEOS Agencies and via 
strong collaboration with other CEOS Working Groups and Virtual Constellations. It also identifies multi-agency implementation teams for each product, reviews their actions, and ensures that a coherent implementation plan exists for each and every product. In defining these implementation plans, WGClimate fully accounts for other pertinent international initiatives, such as Sustained, Coordinated Processing of Environmental Satellite Data for Climate Monitoring (SCOPE-CM [36]). Within SCOPE-CM, the contributing organizations coordinate their scientific and technical development activities and cooperate on the basis of shared and distributed responsibilities for the generation of global products.

\section{CDR Products and Applications}

CDR products and derived CIRs have been widely used in various applications of environment and climate change research, including resource and risk management, decision support, and commercial impact assessment. Some of these CDR products and their important applications are briefly discussed in the following subsections.

\subsection{CDRs and Scientific Applications}

It is beyond the scope of this overview article to describe all application of CDRs. Therefore, we aim to provide a brief overview of the major international efforts to produce CDRs for scientific applications and show the breadth of climate variables that they cover. There are major initiatives across the globe for creating CDRs. We describe three such programs to create CDRs along with their major scientific applications.

\subsubsection{NOAA Climate Data Record Program}

The mission of National Oceanic and Atmospheric Administration's (NOAA) Climate Data Record Program (CDRP) is to develop and implement a robust, sustainable, and scientifically defensible approach to producing and preserving climate records from satellite data [3]. The CDR Program provides FCDRs for numerous satellite records and TCDRs for atmospheric, oceanic and terrestrial variables, a few of which are summarized here. The full operational CDRs produced and sustained by NOAA CDRP along with their related documents and source codes can be freely accessed at the CDRP website [37].

- MSU/AMSU brightness temperatures: These are inter-calibrated brightness temperatures from microwave temperature sounding instruments: Microwave Sounding Unit (MSU)/Advanced Microwave Sounding Unit (AMSU), on-board NOAA and METOP (Meteorological Operational Satellite) operational polar orbiting satellites $[38,39]$. These FCDRs are fundamental to climate monitoring because tropospheric and stratospheric temperature changes can be estimated from these datasets [40].

- AVHRR Reflectance-PATMOS- $x$ : The PATMOS-x product [32] provides a reflectance CDR for the visible channels of AVHRR on the Polar Operational Satellites (POES) and METOP platforms. Due to its length, the AVHRR data record offers a unique resource for multi-decadal climate studies. PATMOS-x improved the quality of the dataset through work with re-calibrating and re-navigating the data. The resulting TCDRs, such as various cloud properties, provide confidence to climate variability studies over the last 30 years [41].

- Geostationary Brightness Temperature - GridSat B1: The Gridded Satellite (GridSat-B1) data [19] facilitates geostationary data usage for a wide range of users. The complete dataset provides data from 3 channels: the CDR-quality infrared window channel (near $11 \mu \mathrm{m}$ ), the visible channel (near $0.6 \mu \mathrm{m}$ ) and the infrared water vapor channel (near $6.7 \mu \mathrm{m}$ ). The three-hourly International Satellite Cloud Climatology Project (ISCCP) B1 data are regridded to a 0.07 degree latitude equal-angle grid, resulting in a CDR that spans from 1980-present. The CDR merges satellites by selecting the nadir-most observations for each grid point. There are wide ranges of applications 
for this dataset. For example, Bain et al. [42] used this data set to derive ITCZ climatology in the East Pacific.

- HIRS Channel 12 Brightness Temperature: The high-resolution infrared radiation sounder (HIRS) channel $12(\sim 6.52 \mu \mathrm{m})$ measures upper tropospheric humidity. HIRS level-1b data in conjunction with cloud-clearing, limb-correction, and inter-satellite calibration [43] provide necessary inputs to produce the Brightness Temperature FCDR. This dataset is extensively used in climate studies due to the high importance of upper tropospheric humidity in our climate system [44]. It is worth noting that there is a European Union (EU) project named fidelity and uncertainty in climate data records from earth observations (FIDUCEO [45]) which has embarked on creating an FCDR covering all channels of HIRS instrument.

- $\quad$ SSMI(S) Brightness Temperatures: The FCDR of Special Sensor Microwave Imager/Sounder $(\mathrm{SSMI}(\mathrm{S}))$ brightness temperature $(\mathrm{Tb})$ dataset comprises window-channel $\mathrm{Tb}$ from a series of 10 microwave radiometers flown on board the Defense Meteorological Satellite Program (DMSP) series of satellites [46-48]. Six SSM/I instruments first flown on DMSP F08 in July 1987 provide the inter-calibrated data along with the data from four currently operational SSMIS instruments. This FCDR dataset provides input into a number of TCDR products including precipitation, sea surface wind speed, sea ice extent, snow cover, cloud liquid water, and total precipitable water content. Numerous publications have used this dataset to look at climate applications [49].

- PERSIANN Precipitation CDR: The CDR of Precipitation Estimation from Remotely Sensed Information [22] using Artificial Neural Networks (PERSIANN) is produced primarily by using infrared brightness temperature data from GridSat-B1 FCDR as input to the trained PERSIANN algorithm. Rainfall estimates are bias-corrected using monthly Global Precipitation Climatology Project (GPCP) data. PERSIANN CDR is a daily product at $1 / 4^{\circ}$ spatial resolution. It spans 1983 to current (updated quarterly) with a nearly global coverage: from $60^{\circ} \mathrm{S}$ to $60^{\circ} \mathrm{N}$ latitude and $0^{\circ}$ to $360^{\circ}$ longitude. This global precipitation dataset is intended to support climatologists, hydrologists, hydrometeorologists, and hydroclimatologists in various forms of climate research and application, including extreme event (flood and drought) analysis [50].

- AVHRR Aerosol Optical Thickness: AVHRR AOT CDR provides an optical measure of aerosol column loading derived from the global ocean pixel-level PATMOS-x AVHRR clear-sky reflectance CDR at $0.63 \mu \mathrm{m}$ channel on both daily and monthly scales. The current operational version of the product spans from 1981 to 2009 and has been used to study the long-term trends of aerosol loading [34] and air quality changes in coastal regions [51].

- AVHRR PATMOS- $x$ cloud properties: These products provide high quality CDRs of multiple cloud properties along with AVHRR brightness temperatures [32]. Different algorithms were used to derive these cloud products during daytime and nighttime. They are output together with the inter-calibrated radiances and selected ancillary data as the Level-2b daily CDR products, which allow other applications and CDRs to be generated from the PATMOS-x CDR data, such as the above AVHRR AOT CDR (also in Figure 2). The PATMOS-x CDR data span 1978 to present and will be forward extended through 2020. The products have many applications, such as detecting and studying climate variability [52], verifying and validating climate models [53], energy and hydrology studies [54], and supporting aviation safety [55].

- Ocean Near-Surface Atmospheric Properties and Heat Flux: Near-surface atmospheric temperature, humidity, and wind along with similar values at the sea surface describe essential aspects of the air-sea exchange. The Special Sensor Microwave/Imager (SSM/I), a passive microwave sensor, along with the sea surface temperature CDR provide this data after the application of a combination of statistical techniques using neural networks and diurnal warming parameterizations [56]. From these data, the near-surface fluxes of latent and sensible heat calculations produce a CDR on a three-hourly $0.25^{\circ}$ resolution grid over the global ice-free oceans. The products have been widely used in the surface energy budget analysis and water cycle study $[57,58]$. 
- Outgoing Longwave Radiation: The amount of terrestrial radiation that is released to space and, by extension, the amount of cloud cover and water vapor that intercepts radiation in the atmosphere defines the daily and monthly Outgoing Longwave Radiation (OLR) CDR. Data (Level-1b) from the HIRS and GridSat-B1 are the primary inputs into the daily OLR record. Application of a combination of statistical techniques, including OLR regression, instrument ambient temperature prediction coefficients, and inter-satellite bias corrections produce the final record [59]. The products have been widely used in various applications, such as radiation budget studies and Madden-Julian oscillation (MJO) diagnostics and forecasts [26].

- Sea Ice Concentration: The sea ice concentration CDR provides a daily and monthly, time series of sea ice concentrations for both the north and south polar regions on a $25 \mathrm{~km} \times 25 \mathrm{~km}$ grid [60]. These data comprise an estimate of the fraction of ocean area covered by sea ice that is produced by combining concentration estimates created using two algorithms developed at the National Aeronautics and Space Administration (NASA) Goddard Space Flight Center (GSFC). Gridded brightness temperatures acquired from a number of DMSP passive microwave radiometers provide the necessary input to produce the CDR. The product has applications that include studying and monitoring climate variability and providing guidance for the industries of shipping and fisheries.

- Sea Surface Temperature-Optimum Interpolation: The NOAA $1 / 4^{\circ}$ daily Optimum Interpolation Sea Surface Temperature (or daily OISST) provides complete ocean temperature fields constructed by combining bias-adjusted observations from different platforms (satellite, ships, buoys) on a regular global grid, with gaps filled in by the interpolation [23]. Satellite data from AVHRR provides the main input which permits the high temporal-spatial coverage beginning in late 1981 to the present; this must be adjusted to the buoys due to erroneous cold SSTs following the Mt Pinatubo and El Chichön eruptions. Applications include climate modeling, resource management, ecological studies on annual to daily scales [61].

- AVHRR Surface Reflectance: Surface reflectance provides a measure of the fraction of incoming solar radiation that is reflected from Earth's surface in two spectral ranges of the AVHRR sensors: red (around $0.64 \mu \mathrm{m}$ ) and the near infrared (around $0.86 \mu \mathrm{m}$ ). As a key variable, surface reflectance supplies the primary input for essentially all higher-level land surface geophysical parameters, such as NDVI and LAI CDRs. The surface reflectance CDR delivers valuable surface information dating back to 1981 as a daily product on a $0.05^{\circ}$ grid [62]. It has been used to study long-term climate variability along with climate model verification and validation.

- Land Area Index and FAPAR: The Leaf Area Index (LAI) and Fraction of Absorbed Photosynthetically Active Radiation (FAPAR) are biophysical variables that characterize the canopy and photosynthetic activity of plants. The one-sided green leaf area per unit ground surface area describes the LAI dataset. The fraction of the incoming solar radiation in the Photosynthetically Active Radiation spectral region that is absorbed by the plants defines the FAPAR data set. The LAI/FAPAR CDR is a daily product on a $0.05^{\circ}$ grid from 1981 to present derived from AVHRR sensors [62]. It can be used to evaluate vegetation stress and forecast agricultural yields $[63,64]$.

- $\quad$ Normalized Difference Vegetation Index: The Normalized Difference Vegetation Index (NDVI) CDR summarizes the measurement of surface vegetation coverage. The surface reflectance calculations in the red and the near infrared spectral bands derived from AVHRR provide NDVI values [62]. The NDVI CDR produces daily output on a $0.05^{\circ}$ grid, from 1981 to present. This consistent, long-term record of remotely sensed vegetation observations allows scientists to characterize the health of vegetation in different regions across the world [63,64].

- Snow Cover Extend (Northern Hemisphere): The weekly Northern Hemisphere (NH) Snow Cover Extend (SCE) CDR spans the period from late 1966 to present, comprising the longest satellite-based CDR of any environmental variable. This CDR combines the NOAA visible satellite-based SCE analyses generated weekly through May 1999 and daily since June 1999 to 
form a continuous NH record [65]. The resulting continental SCE product informs climate studies, climate change monitoring, and climate model validation [66,67].

\subsubsection{ESA Climate Change Initiative}

Europe Space Agency's (ESA's) Climate Change Initiative (CCI [68]) is making full use of Europe's Earth observation space assets to exploit robust, long-term global records of essential climate variables, such as greenhouse-gas concentrations, sea-ice extent and thickness, and sea-surface temperature and salinity. This sub-section briefly describes some of the CCI initiatives:

- Aerosol CCI: Aerosol CCI [69,70] was a three year intensive algorithm development effort that incorporated sensitivity analysis, validation and inter-comparison activities [71], along with a round robin exercise of seven different retrieval algorithms [72]. It produced: (1) AOT and Ångström exponent (AE); (2) Stratospheric extinction profiles and aerosol optical thickness; and (3) Absorbing aerosol index (AAI). AOT/AE datasets are provided for two main purposes: climate aerosol model evaluation, data assimilation into global aerosol re-analysis/forecasting model systems. The stratospheric dataset is provided as a correction to the total column AOT retrievals (mostly relevant in the case of major volcanic eruptions) and for stratospheric climate model evaluation. The AAI dataset so far is the only information for aerosol absorption (though only qualitative at present) has been prepared for comparison to model datasets by developing a model AAI simulator and analyzing major sensitivities.

- GHG-CCI: The Greenhouse Gas (GHG)-CCI [73] data products contain information on regional $\mathrm{CO}_{2}$ and $\mathrm{CH}_{4}$ surface fluxes (emissions and uptake) and, therefore, can be used to improve our knowledge of GHG surface fluxes. These products are generated with GHG-CCI "ECV Core Algorithms" (ECAs). ECAs are algorithms to retrieve dry-air column-averaged mole fractions of carbon dioxide $\left(\mathrm{CO}_{2}\right)$ and methane $\left(\mathrm{CH}_{4}\right)$, denoted $\mathrm{XCO}_{2}$ (in ppm) and $\mathrm{XCH}_{4}$ (in ppb) from two satellite instruments: SCanning Imaging Absorption spectroMeter for Atmospheric CHartographY (SCIAMACHY) onboard Environmental Satellite (ENVISAT) (2002-2012) and Thermal And Near infrared Sensor for carbon Observation - Fourier Transform Spectrometer (TANSO-FTS) onboard Greenhouse gases Observing SATellite (GOSAT) (2009-ongoing).

- SST CCI: The first version of the long-term SST CCI Analysis product version are derived from infrared imagery obtained from several Earth-observing satellite missions, combined to give daily, spatially complete information over the global oceans spanning 20 years [74]. The principal recommended applications are for climate research applications requiring 20 years of stable, low bias records of SST. The dataset is particularly valuable if a representation of global SST is required that is independent of in situ SST measurements.

- Ocean-Color CCI: The ESA-CCI ocean color ECV dataset [75] provides ocean color data, with a focus on Case 1 (open ocean, not coastal) waters, which can be used by climate change prediction and assessment models. The dataset is created by band-shifting and bias-correcting atmosphere corrected MEdium Resolution Imaging Spectrometer (MERIS) and Aqua Moderate Resolution Imaging Spectroradiometer (MODIS) data to match Sea-Viewing Wide Field-of-View Sensor (SeaWiFS) data, merging the datasets and computing per-pixel uncertainty estimates.

- CCI Sea Ice Concentration: ESA-CCI Sea Ice Concentration (SIC) dataset [76] provides SIC and its uncertainties (both in \% from 0 to 100) for both Northern hemisphere (NH) and Southern hemisphere (SH). Each file includes daily averaged SIC, processing status, three estimates of uncertainty, flags of SIC values retrieved outside the physical range of $0 \%-100 \%$, and relevant metadata information.

- CCI Soil Moisture: This soil moisture product is being developed and provided in the frame of the ESA Climate Change Initiative. The global soil moisture data set has been generated using active and passive microwave space-borne instruments and covers the 35-year period from November 1978 to December 2013 [77]. 
- CCI Land Cover: ESA-Land Cover (LC) CCI databases [78] consist of: (a) three global LC maps at $300 \mathrm{~m}$ spatial resolution for three epochs centered on the years 2010 (2008-2012), 2005 (2003-2007) and 2000 (1998-2002). The maps were obtained using the full MERIS archive (2003-2012) and the Satellite Pour 1'Observation de la Terre (SPOT)-Vegetation time series. The legend counts 22 classes defined using the Food and Agriculture Organization (FAO) Land Cover Classification System (LCCS); (b) three global climatological seven-day time series over the 1998-2012 period representing typical seasonal dynamics of the land surface at the pixel level: the vegetation greenness as described by the Normalized Vegetation Index, the snow occurrence and the Burnt Areas (BA) distribution. They are compiled from existing global datasets; and (c) Global surface reflectance (SR) time series of the whole MERIS Full and Reduced Resolution archive (2002-2012) provided in seven-day composites.

\subsubsection{EUMETSAT's Climate Monitoring SAF}

European Organization for the Exploitation of Meteorological Satellites' (EUMETSAT's) Satellite Application Facility (SAF) on Climate Monitoring (CM) (CMSAF [79]) develops, generates, archives, and distributes high-quality satellite-derived products of the global energy and water cycle and related sustained services in support to understand our climate. One of the major highlights of CMSAF is the long-term commitment, the funding is currently guaranteed until 2035. The major datasets from CMSAF are:

- $\quad$ SSM/I FCDR: The CM SAF Fundamental Climate Data Record of SSM/I Brightness Temperatures provides homogenized and inter-calibrated brightness temperatures from the six SSM/I radiometers aboard F08, F10, F11, F13, F14, and F15 of DMSP. The applications of this FCDR are similar to those described above for the NOAA SSMI Brightness Temperature CDR.

- $\quad$ Free Tropospheric Humidity (FTH): FTH is an important climate variable due to its large sensitivity to OLR and thus a strong feedback factor in the Earth's climate system. Monitoring of FTH globally is therefore important to understand our changing climate. However, measuring humidity in the free troposphere is a challenge and there are only a few datasets available for FTH. The FTH dataset produced by the EUMETSAT's CMSAF [80] are derived from Meteosat (Meteorological Satellites) 1st and 2nd generation geostationary satellites. FTH is a key climate variable that plays a very important role in Earth's radiation budget, however, FTH is not well simulated by current climate models [81].

- HOAPS: The Hamburg Ocean Atmosphere Parameters and Fluxes from Satellite (HOAPS) data set [82] is a satellite-based climatology of precipitation, evaporation, freshwater budget (evaporation minus precipitation), related turbulent heat fluxes and atmospheric state variables as well as liquid water path and total column water vapor over the global ice free oceans.

- CLARA-A1: CM SAF Clouds, Albedo and Radiation AVHRR data edition 1 (CLARA A1) surface radiation properties, cloud properties, and surface albedo datasets [83] are a global dataset derived from measurements of the series of AVHRR on the NOAA satellite series including METOP-A satellite. Its applications are similar to the NOAA AVHRR cloud CDRs.

- SARAH: The Surface Solar Radiation Data Set-Heliosat (SARAH) [84] is a satellite-based climatology of the solar surface irradiance, the surface direct normalized irradiance and the effective cloud albedo derived from satellite observations of the visible channels of the Meteosat Visible and Infrared Imager (MVIRI) and Spinning Enhanced Visible and Infrared Imager (SEVIRI) instruments onboard the geostationary Meteosat satellites. The data are available from 1983 to 2013 and cover the region $\pm 65^{\circ}$ longitude and $\pm 65^{\circ}$ latitude. The products are available as monthly, daily, and hourly averages on a regular latitude/longitude grid with a spatial resolution of $0.05^{\circ} \times 0.05^{\circ}$. 


\subsection{Industry and Commercial Applications}

Due to the merits of CDRs, they are widely applied in climate-related scientific research, meanwhile, CDRs, especially ICDRs and TCDRs, are also utilized by industry and commercial companies and organizations to create commercial values, in the energy, food, and transportation industries. The applications fall into several categories of social benefits that are described in Section 4 .

One example of the CDR application from the energy industry is demonstrated by 3TIER [85], currently a subsidiary company of Vaisala, one of the world leaders in weather monitoring and measurement. 3TIER is running an assessment service for renewable energy projects. By combining SDRs from GOES, Meteosat, GMS and MTSAT (Multi-functional Transport Satellites), 3TIER developed a satellite derived ICDR composed of more than 15 years of hourly Global Horizontal Irradiance (GHI), Direct Normal Irradiance (DNI), and Diffuse Horizontal Irradiance (DIF) at a horizontal resolution of about $3 \mathrm{~km}$ covering the entire globe [86]. This ICDR is serving as the data basis for 3TIER Solar Prospecting tool for solar power plant site selection and efficiency estimation. The solar radiation CDR (SARAH) provided by CM SAF has also been successfully applied in the estimation of solar energy yield, by adapting it into the Photovoltaic Geographical Information System (PV-GIS) and improving PV-GIS performance obviously [87].

CDRs also play an important role in the natural gas market. During the heating season, the price of natural gas is closely related to the temperature anomaly, which is connected with Madden-Julian oscillation (MJO). The MJO, in turn, can be predicted by the SST anomaly and outgoing longwave radiation anomaly $[26,27,29]$. The derivation of SST and OLR anomaly indices depends on the corresponding CDRs.

In the field estimating food production, CropWatch [88] is working on the long-term series of satellite vegetation observation. Normalized difference vegetation index time series are derived from CDRs of MODIS/AVHRR to estimate the crop yield, while high-resolution images from LandSat, EnviSat, and Radarsat are used to estimate the crop acreage.

For marine fisheries, satellite CDRs including ocean color, sea surface temperature, and sea surface salinity are retrieved and archived to support not only fish searching, but also marine resources management for more sustainable use [89,90].

CDRs are also helping the transportation industry. High resolution land images have been adopted in network transportation analyses [91]. For marine transportation, Synthetic Aperture Radar (SAR) images have been used for ice navigation in the Northern Sea Route [92], while snow cover extent CDR [93] also contributes to the shipping route design in Arctic regions.

Long-term remote sensing data records are also applied in the insurance industry for assessment of damage from fire [94,95], flood [96], hail [97], and drought [98]. By carefully reviewing remote sensing applications for the insurance industry, Leeuw et al. [99] suggest remote sensing community should work more closely with insurance experts to promote more remote sensing application in insurance business.

\section{Societal Benefit}

It is helpful to briefly review the societal benefit of space remote sensing (RS), the foundation of satellite CDRs, in order to discuss the societal benefit of satellite CDRs. Most space RS applications could be inherited and extended to satellite CDR applications, except for real-time applications. Conversely, due to the short period of satellite CDR's history of production and application (comparing to space RS), the societal benefit of satellite CDRs still needs to be explored. Furthermore, potential societal benefits of satellite CDR applications could be revealed by reviewing space RS applications, especially from end-users' point of view.

The advancement of space RS observations of the Earth is driven by scientific inquiries and societal needs from the user sectors, such as agriculture, forestry, fishery, energy, health, water, transportation, and tourism. While each user sector has its own requirements, the retrieved meteorological and climatological information and atmosphere, land, and ocean conditions in various spatial and temporal 
coverages and resolutions, such as temperature, humidity, and precipitation, and surface condition, are prerequisites of almost every user sector, which will be discussed below.

\subsection{Agriculture}

Typical applications of the satellite RS observation on agriculture are precision agriculture and viticulture.

Crop monitoring is a core part of the precision agriculture management, whose goal is optimizing returns on inputs while preserving resources. It uses multispectral or hyper-spectral observations from visible and near infrared spectroradiometers; monitoring crops provides the capability to respond to the crop dynamics on particular field zone. The related information enables the agriculture companies to manage crop vegetation control, forecast crop yield, and optimize management decisions. Based on this information, investors and investment analysts can carry out potential estimation, make sustainable forecasts, and investment decisions; insurance brokers can calculate scale of rates and insurance premiums, and evaluate clients' claims verification. More importantly, some extremity of the information may be related to food security or ecological issues in the eyes of state or federal government [100]. The information of land use history may be beneficial by providing the best timing and place for a specific crop to grow, and help with inter-annual planning such as rotation and fallow.

Similarly, in the context of the grape and wine industry, precision viticulture may be defined as monitoring and managing spatial variation in any physical, chemical, and biological variables related to "productivity" (e.g., grape yield, Baume, pH, and total phenolics) within a single vineyard [101,102]. The information includes environmental conditions, such as microclimate, topography, and soil, which have significant effects on wine quality, though their importance may differ at regional scales and the scale of individual vineyard blocks. Ultimately, yield and quality information may be estimated from monitoring of these factors using space remote sensing techniques and resulted CDRs and CIRs.

\subsection{Forestry}

Traditional applications of forestry include the mapping of forest area and health of the canopy. These mainly depend on multi-spectral observation since forest canopies respond to visible and infrared light differently. The observed canopy spectral properties can then be used to derive several types of vegetation indices (VI), or leaf area index (LAI) with the aid of radiative transfer calculations and vegetation classification map [103]. Different values of these indices may indicate barren, sparse, or dense canopy, thus it is natural to extend the application to monitoring land use and land change, deforestation (planned or illegal), forest seasonality in Amazon region [104,105], and response to extended drought in Congo region [63]. With long-term climate data, our understanding of the forest could be more consistent [106].

Since the forest is the major storage of biomass on land area, its carbon exchange with atmosphere through photosynthesis and respiration becomes extremely important to understanding climate change. For this reason, forest management has a role to play in climate change policy and the development of the global carbon markets [107]. This duty can be performed through the synergy of satellite observation, ecological and economic modeling.

On the other hand, fires are inevitable companions of forests across the world, which can be detected from visible, thermal infrared, and active microwave, as well as a combination of these three bands [108]. In time, wildfire hazard monitoring may serve as a crucial part of the fire response system, and the time series of a wildfire hazard CDR may serve in better prevention.

\subsection{Fisheries}

"Satellite remote sensing has been an important technique in fisheries research, management and harvesting, because it provides synoptic ocean measurements for evaluating environmental influences on the abundance and distribution of fish population and allows ecological analyses at community and ecosystem scales $[89,109-111]$. Satellite images combined with other data can be analyzed to find ocean 
environmental conditions suitable for fish aggregation. Therefore, forecast models depend heavily on inputs from satellite sensors, in addition to in situ measurements and observations. Fisheries-related satellite data include SST, ocean color (productivity), turbidity, sea surface salinity, ocean fronts and gyres, sea surface currents, winds and waves" [90].

Early studies showed that satellite-derived fishery-aid charts could reduce $25 \%-50 \%$ of some US commercial fisheries search time [112]. Now, confronting the situation that nearly $80 \%$ of the world fish stocks are either fully exploited or overexploited, effective monitoring and management is required for (1) sustainable use of marine resources, e.g., to monitor fishing fleets at night due to their use of lights to prevent illegal fishing in protected regions of the ocean [113] and (2) protection of fish habitat and ocean ecosystem, such as coral reefs [114], and satellite remote sensing continues to fulfill this requirement.

With the relatively long CDR data set, humans may achieve a more comprehensive knowledge of fish dwelling and migration, and their timing, and hence more strategic fisheries management.

\subsection{Energy}

Satellite observation may exert impacts on the following three components in energy system: demand, supply, and distribution. Accordingly, the CDR relative data sets may delve deeper into these components, and link them with other factors, such as population and/or gross domestic product.

Among an exhaustive list of energy supplies, altogether 9 kinds, 5 of them can be potentially assessed using remote sensing technologies, including biomass, solar [87], wind, hydro, and heat transfer [115]. Wind energy, for example, transforms the kinetic energy of wind into electricity using rotating a turbine. Key variables to estimate wind energy are wind speed and direction, which can be measured from several onsite and space-borne instruments. A wind climatology data set (or CDR) could greatly help select the sites for a wind farm. Similarly, satellite imagery and CDR products can help in the exploration of oil, gas, and minerals.

According to a report of Global Science \& Technology, Inc. Greenbelt, MD, USA [116] in 2007, power distribution systems were damaged with dry conditions and Santa Ana winds, and as a result, fueled massive fires burning 13\% of San Diego Gas \& Electric's service territory. The utility was found liable and the company paid $\$ 2$ billion in hundreds of settlement cases. Afterward, they created an early warning and operational maintenance system using historical climate data. In a similar dry condition during 2014, the system saved the utility billions of dollars in avoided liability.

\subsection{Health}

The contribution of satellite remote sensing on human health may rely on monitoring infectious diseases, air quality, and water quality. With experience from remote sensing, a climatology from CDR may help with long-range prevention and protection.

Infectious diseases such as malaria, yellow fever, diarrhea and tuberculosis, are a heavy burden on human populations, killing millions of people each year, a major cause of work loss [117]. Even though it is not possible to directly identify mosquitoes in satellite data, one can locate mosquitoes and their effects, such as malaria, with high accuracy by identifying their habitat (commonly soil, water, rocks, flora, fauna, and air). Many successful examples have been reported, e.g., Hayes et al. [118] used Landsat data to identify mosquito larval habitats in Nebraska and South Dakota, USA, based on their association with freshwater plant communities. By cumulating the digital database with excellent temporal and spatial references, it is possible to analyze the relationships of vectors and diseases at landscape-level, and set alerts from season to season.

Satellite remote sensing of trace gases and aerosols for air quality applications has a rich history, and it has evolved dramatically over the last decade [119] by employing varieties of passive and active techniques. Aerosols, tropospheric $\mathrm{O}_{3}$, tropospheric $\mathrm{NO}_{2}, \mathrm{CO}, \mathrm{HCHO}$, and $\mathrm{SO}_{2}$ are not directly observed, but retrieved through calculating the atmospheric composition that best reproduces the observed radiation. Major applications of retrieved trace gases and aerosols fall into three categories: 
analyses and forecasts of events that affect air quality, inference of surface air quality, and estimates of emissions. As an example of the first category, Hutchison [120] presented a case study in which MODIS satellite data show pollution transport that led to 150 health advisories in Texas. Also, Zhao [51] studied air quality changes in coastal megacities by examining the long-term trends of aerosol optical thickness using AVHRR AOT CDR product.

To analyze water quality, suspended sediments, algae, aquatic vascular plants, and temperature need to be monitored, as these are the key pollutants listed by the Environmental Protection Agency, which estimated that approximately 40 percent of U.S. waters do not meet minimum water quality standards [121]. For example, using Landsat Thematic Mapper Data, suspended sediment in Lake Chicot can be mapped [121]. Higher spatial and spectral resolution may achieve better performance.

\subsection{Water}

It is beyond the limitation of this paper to enumerate the importance of water to human life, and the approaches to monitor water in various forms. Generally, water related applications fall into the following categories: health, flood, water resources and management [122]. We have addressed health category in Section 4.5, here we list briefly other categories.

With increasing populations and water usage coupled with climate variability and change, water issues are being reported by numerous groups as the most critical environmental problems facing us in the 21st century [123]. At the turn of this century, over 2 billion people on the Earth lacked adequate drinking water or sanitation; projected to 2025, population growth is expected to impact water availability more significantly than the impacts of greenhouse warming on water systems [122]. To address this water resource and management issue, a group of satellite-borne sensors keep monitoring evaporation [124], atmospheric river [125], clouds and precipitation [126], surface water extent, elevations, water level, groundwater [127], soil moisture [128], etc. These Earth observations provide information for informed decision making and for monitoring conditions and progress at multiple spatial and temporal scales. Hence, most physical variables relating to these processes are identified as ECVs, and archived as CDRs. For example, other than directly monitoring global precipitation [22], the PERSIANN-CDR can contribute to applications such as hydrological changes and flood increase [129], fresh water resources over water-stressed islands [130], and more.

Climate variability and changes, together with land use changes, have altered naturally occurring flood hydrographs. The patterns and extents of floods directly impact the economies, lives, and health of communities within flooded areas. As a consequence, floods and associated landslides caused more than $55 \%$ of the worldwide significant natural disasters during 2002-2011; they killed over 65,000 people, affected over 1.1 billion people and cost an estimated $\$ 280$ billion (US Dollars in 2011), according to World Disaster Report [131]. The contribution of satellite remote sensing to this issue is two-fold: (1) directly mapping inundation area using optical or Synthetic Aperture Radar imagery; and (2) using remotely observation and derived CDRs of precipitation, land cover, vegetation, topography, etc. as inputs to hydrologic models for flood monitoring and forecasting [132].

Due to the vital importance of water, the institutions, such as National Science Foundation, Department of Defense, NOAA and NASA have their own water related projects, e.g., NASA Applied Sciences Program [133] has supported such projects to meet the societal requirements.

\subsection{Transportation}

Satellite observations have successfully helped transportation in the following aspects: (1) environmental impact assessment; (2) infrastructure management; and (3) safety, hazards and disasters assessment [134]. These were achieved using hyperspectral and high-resolution optical observation, and light detection and ranging (LIDAR). The development of a transportation network, such as a highway system, is always accompanied by urban growth, and both of them would introduce environmental impacts, such as land use and land cover change, ecosystem, and air quality. 
Transportation infrastructure is composed of planning, design, and maintenance of transportation assets, including pavements, bridges, pipelines, rail-lines, harbors, and airports. Remote sensing, together with Geographic Information System (GIS) and Global Positioning System (GPS) may provide information of location and their change through time, include general road centerline, precise road width, traffic count (cars, airplanes, etc.), parking [135], bridge location, corridor location, etc.

Apart from safety and hazards, which are more relating to real-time application, remotely sensed transportation disasters generally come from extreme events (e.g., hurricane, gale), which are identified and separated from the normal condition determined from related CDRs. Now CDR related technology and data products are advancing our awareness and ability to monitor the transportation assets and forecast disastrous events, thus improving the public's avoidance and mitigation responses.

\subsection{Tourism}

The tourism industry is still in the early stages of using satellite observations, and in some aspects the usage is more often in GIS applications [136,137]. Due to the specialty of tourism, the planning and management may overlap with other sectors, such as urban setting, transportation, water quality [138,139], and water level. For example, the issue of forest conservation in protected areas, including national parks $[140,141]$, overlaps with remote sensing applications in the forestry industry.

Some tourism may relate to weather or climate, which need only small efforts from satellite observation community. For example, fall foliage coloration can now be monitored by means of temporally normalized brownness derived from MODIS data [142], the precise position and timing is appreciated by leaf-lovers. Long-term satellite CDR can be beneficial by providing the best coloring time in a statistical sense so that tourists can be better prepared for their travel plan. Similarly, snow in ski areas is valuable information to skiers.

The needs of each public sector may spur the improvement of the observation system and the production chain; new improvements in the technology would in turn expand the coverage and intensity that can apply to the societal benefits. This feedback loop would go endlessly through the life span of the technology.

\section{Conclusion}

To sustain CDR production and service, the transition of algorithms, software, and products from research environment to operational environment, using well-developed standards, processes, and maturity requirements, is necessary. A two-phased research to operation transition is a feasible scheme. The first phase should focus on capturing the data set and the software that generated it along with other relevant information (documentation, metadata, read me files, etc.). The second phase involves "operationalizing" the software that generates the data set with a focus on software rejuvenation for portability and long-term maintenance. All the CDR products (source codes, documents, and datasets) should be freely accessible and with a production process that is publicly transparent. Transparency of CDR development and production processes and free open access of data products are essential to maintaining credibility of the CDR products themselves. In addition, further improvement of the operational CDRs through research is also necessary, especially when new observations and technology become available. The improved products can be treated as a new version of the CDRs and used to replace the old version though another round of $\mathrm{R} 2 \mathrm{O}$ transition.

The application and societal benefit of satellite CDR are more in science in current stage and are going to grow into more societal sectors due to the legacy benefits from the space RS. In the application of societal sectors, though space RS and satellite CDR are similar, space RS is more practical and in a timely manner, while satellite CDR is more strategic and far reaching. For example, from the RS, one may determine in real-time, what is the good place for fish aggregation, while from CDR, one may gain the knowledge of the long-term spatial-temporal distribution of fish schools. Combined with the knowledge of the fish's life cycle, it is more convenient to estimate yearly fishing yield, manage fishing moratorium, design ship routes to avoid destroying the fish habitat, and design tourist routes to visit 
fish schools underwater. The production of ICDR in addition to FCDR and TCDR can also expand CDR user community from delayed-time users to near-real time users in various commercial sectors. The derivation of CIR can enhance satellite CDR application in decision making and public service. Leveraging the broader applications of environment data records (EDRs) from satellite remote sensing is also an effective way of enhancing CDR application. For examples, extending climate data records to broader long-term reference environment data records (REDRs) will benefit more user sectors.

Climate reanalysis data is another type of long-term climate record widely used in climate applications. Reanalyses are produced by a data assimilation system, which is a climate forecasting model adjusted to the observational data (such as satellite and in-situ measurements) using some numerical bias correction techniques [143-145]. The diagnostic meteorological fields output from the data assimilation system are climate reanalysis variables, which are widely used for climate studies. The assimilation in the system is normally performed on limited observational variables, such as radiance, temperature, etc. but many diagnostic meteorological fields are output on a regular grid as reanalysis variables for broader climate applications. However, any errors contained in the observational variables used for the assimilation will propagate into the output diagnostic variables even though the numerical bias correction techniques have been used to minimize the error propagation. Improving the quality of the input observational data (such as using CDRs as inputs instead of EDRs) for the assimilation system will reduce the error propagated from the input observational variables into the reanalysis variables. Currently, satellite EDRs are widely used as the observational input for the data assimilation systems to produce climate reanalysis products. Thus, we should perform the inter-comparison of CDR and reanalysis products and promote replacing satellite EDRs with CDRs in the future reanalysis production.

Climate data records are becoming increasingly important for numerous applications and societal benefit areas. This requires increased coordination and collaboration of CDR development, production, archive, dissemination, application, and service among scientists and organizations. Moreover, extending climate data records to broader long-term reference environment data records to benefit more user sectors will be a strategic step forward. In this way, we may achieve the goal of developing and implementing a robust, transparent, sustainable, and scientifically defensible approach for developing, producing, preserving, and provisioning CDRs and REDRs from satellite observations and in-situ measurements and thus providing an end-to-end data service to various user sectors and decision makers.

Acknowledgments: We acknowledge Remote Sensing for hosting the Special Issue on Satellite Climate Data Records and Applications. X. Zhao, K. Knapp and W. Yang acknowledge the support from the NOAA Climate Data Record Program. The research of Hui Lu is jointly supported by the National Basic Research Program of China (grant No. 2015CB953703) and the National Natural Science Foundation of China (41371328 and 91537210). Three anonymous reviewers' comments and suggestions are helpful for the improvement of the manuscript. The views, opinions, and findings contained in this paper are those of the author(s) and should not be construed as an official National Oceanic and Atmospheric Administration or U.S. Government position, policy, or decision.

Author Contributions: W. Yang contributed to the write-up of Sections 1, 4 and 5; V. O. John contributed to the write-up of Sections 3.1 and 4; X. Zhao contributed to the write-up of Sections 1, 2 and 5; H. Lu contributed to the write-up of Sections 2 and 3.2; K. Knapp improved and polished the whole paper.

Conflicts of Interest: The authors declare no conflict of interest.

\section{Abbreviations}

The following abbreviations are used in this manuscript:

$\begin{array}{ll}\text { AAI } & \text { Absorbing Aerosol Index } \\ \text { AE } & \text { Ångström Exponent } \\ \text { AMSU } & \text { Advanced Microwave Sounding Unit } \\ \text { AOT } & \text { Aerosol Optical Thickness } \\ \text { AVHRR } & \text { Advanced Very High Resolution Radiometer }\end{array}$




\begin{tabular}{|c|c|}
\hline BA & Burnt Area \\
\hline CCI & Climate Change Initiative \\
\hline $\operatorname{CDR}(s)$ & Climate Data Record(s) \\
\hline CDRP & CDR Program \\
\hline CEOS & Committee on Earth Observation Satellite \\
\hline CGMS & Coordination Group for Meteorological Satellite \\
\hline CIR & Climate Information Record \\
\hline CLARA A1 & Clouds, Albedo and Radiation AVHRR data edition 1 \\
\hline $\mathrm{CM}$ & Climate Monitoring \\
\hline CMSAF & Satellite Application Facility on Climate Monitoring \\
\hline CropWatch & A leading crop monitoring system \\
\hline DMSP & Defense Meteorological Satellite Program \\
\hline DIF & Diffuse Horizontal Irradiance \\
\hline DNI & Direct Normal Irradiance \\
\hline ECAs & ECV Core Algorithms \\
\hline $\mathrm{ECV}(\mathrm{s})$ & Essential Climate Variable(s) \\
\hline $\operatorname{EDR}(\mathrm{s})$ & Environmental Data Records \\
\hline EnviSat & Environmental Satellites (ESA's Earth observation satellite) \\
\hline ESA & Europe Space Agency \\
\hline EU & European Union \\
\hline EUMETSAT & European Organization for the Exploitation of Meteorological Satellites \\
\hline $\mathrm{FAO}$ & Food and Agriculture Organization \\
\hline FAPAR & Fraction of Absorbed Photosynthetically Active Radiation \\
\hline FCDR & Fundamental CDR \\
\hline FIDUCEO & Fidelity and Uncertainty in Climate Data Records from Earth Observations \\
\hline FTH & Free Tropospheric Humidity \\
\hline GCOS & Global Climate Observing System \\
\hline GHI & Global Horizontal Irradiance \\
\hline GHG & Greenhouse Gas \\
\hline GIS & Geographic Information System \\
\hline GOSAT & Greenhouse gases Observing SATellite \\
\hline GPS & Global Positioning System \\
\hline GridSat & Geostationary IR Channel Brightness Temperature \\
\hline GSFC & Goddard Space Flight Center \\
\hline GS\&T & Global Science \& Technology, Inc. \\
\hline HIRS & High-resolution Infrared Radiation Sounder \\
\hline HOAPS & Hamburg Ocean Atmosphere Parameters and Fluxes from Satellite \\
\hline ICDR & Interim CDR \\
\hline ISCCP & International Satellite Cloud Climatology Project \\
\hline LAI & Leaf Area Index \\
\hline LandSat & $\begin{array}{l}\text { Land Satellites (Joint NASA/USGS satellite series for providing the longest } \\
\text { continuous space-based record of Earth's land) }\end{array}$ \\
\hline LC & Land Cover \\
\hline LCCS & Land Cover Classification System \\
\hline MERIS & MEdium Resolution Imaging Spectrometer \\
\hline Meteosat & Geostationary Meteorological Satellites \\
\hline METOP & Meteorological Operational Satellite \\
\hline $\mathrm{MJO}$ & Madden-Julian oscillation \\
\hline MODIS & Moderate Resolution Imaging Spectroradiometer \\
\hline MSU & Microwave Sounding Unit \\
\hline
\end{tabular}




\begin{tabular}{|c|c|}
\hline MTSAT & Multi-functional Transport Satellites \\
\hline MVIRI & Meteosat Visible and Infrared Imager \\
\hline NASA & National Aeronautics and Space Administration \\
\hline NDVI & Normalized Difference Vegetation Index \\
\hline $\mathrm{NH}$ & Northern Hemisphere \\
\hline NOAA & National Oceanic and Atmospheric Administration \\
\hline NPP & National Polar-orbiting Partnership \\
\hline OISST & Optimum Interpolation Sea Surface Temperature \\
\hline OLR & Outgoing Longwave Radiation \\
\hline PATMOS-x & Pathfinder Atmospheres-Extended \\
\hline PERSIANN & $\begin{array}{l}\text { Precipitation Estimation from Remotely Sensed Information using Artificial } \\
\text { Neural Networks }\end{array}$ \\
\hline POES & Polar Operational Satellites \\
\hline PV-GIS & Photovoltaic Geographical Information System \\
\hline $\mathrm{R} 2 \mathrm{O}$ & Research to Operation \\
\hline Radarsat & Radar Satellites (Canada's commercial Earth observation satellites) \\
\hline REDR(s) & Reference Environment Data Record(s) \\
\hline RS & Remote Sensing \\
\hline SAF & Satellite Application Facility \\
\hline SAR & Synthetic Aperture Radar \\
\hline SARAH & The Surface Solar Radiation Data Set - Heliosat \\
\hline SCE & Snow Cover Extend \\
\hline SCIAMACHY & SCanning Imaging Absorption spectroMeter for Atmospheric CHartographY \\
\hline SCOPE-CM & $\begin{array}{l}\text { Sustained, Coordinated Processing of Environmental Satellite Data for Climate } \\
\text { Monitoring }\end{array}$ \\
\hline SDR(s) & Sensor Data Record(s) \\
\hline SeaWiFS & Sea-Viewing Wide Field-of-View Sensor \\
\hline SEVIRI & Spinning Enhanced Visible and Infrared Imager \\
\hline $\mathrm{SH}$ & Southern Hemisphere \\
\hline SI & International Standards \\
\hline SIC & Sea Ice Concentration \\
\hline SPOT & Satellite Pour l'Observation de la Terre \\
\hline SR & Surface Reflectance \\
\hline SSMI(S) & Special Sensor Microwave Imager/Sounder \\
\hline SST & Sea Surface Temperature \\
\hline TANSO-FTS & $\begin{array}{l}\text { Thermal And Near infrared Sensor for carbon Observation-Fourier Transform } \\
\text { Spectrometer }\end{array}$ \\
\hline TCDR & Thematic CDR \\
\hline TOA & Top of Atmosphere \\
\hline VI & Vegetation Indices \\
\hline VIIRS & Visible Infrared Imaging Radiometer Suite \\
\hline
\end{tabular}

\section{References}

1. Schulz, J.; Albert, P.; Behr, H.D.; Caprion, D.; Deneke, H.; Dewitte, S.; Durr, B.; Fuchs, P.; Gratzki, A.; Hechler, P.; et al. Operational climate monitoring from space: The EUMETSAT satellite application facility on climate monitoring (CM-SAF). Atmos. Chem. Phys. 2009, 9, 1687-1709. [CrossRef]

2. Hollmann, R.; Merchant, C.J.; Saunders, R.; Downy, C.; Buchwitz, M.; Cazenave, A.; Chuvieco, E.; Defourny, P.; de Leeuw, G.; Forsberg, R.; et al. The ESA climate change initiative satellite data records for essential climate variables. Bull. Am. Meteorol. Soc. 2013, 94, 1541-1552. [CrossRef] 
3. Bates, J.J.; Privette, J.L.; Kearns, E.; Glance, W.; Zhao, X.-P. Sustained production of multidecadal climate records-Lessons from NOAA climate data record program. Bull. Am. Meteorol. Soc. 2016. in press. [CrossRef]

4. NRC (National Research Council). Climate Data Records from Environmental Satellites: Interim Report; National Academies Press: Washington, DC, USA, 2004.

5. NRC (National Research Council). Ensuring the Climate Record from the NPOESS and Goes-R Spacecraft: Elements of a Strategy to Recover Measurement Capabilities Lost in Program Restructuring; National Academies Press: Washington, DC, USA, 2008.

6. Cao, C.Y.; Xiong, X.X.; Wu, A.H.; Wu, X.Q. Assessing the consistency of AVHRR and MODIS L1B reflectance for generating fundamental climate data records. J. Geophys. Res. Atmos. 2008, 113. [CrossRef]

7. Heidinger, A.K.; Cao, C.; Sullivan, J.T. Using moderate resolution imaging spectrometer (MODIS) to calibrate advanced very high resolution radiometer reflectance channels. J. Geophys. Res. 2002, 107, 4702. [CrossRef]

8. Cao, C.; Weinreb, M.; Xu, H. Predicting simultaneous NADIR overpasses among polar-orbiting meteorological satellites for the intersatellite calibration of radiometers. J. Atmos. Ocean. Technol. 2004, 21, 537-542. [CrossRef]

9. Smith, G.R.; Levin, R.H.; Abel, P.; Jacobowitz, H. Calibration of the solar channels of NOAA-9 AVHRR using high altitude aircraft measurements. J. Atmos. Ocean. Technol. 1988, 5, 631-639. [CrossRef]

10. Stone, T.C.; Kieffer, H.H. Use of the moon to support on-orbit sensor calibration for climate change measurements. Proc. SPIE 2006, 6296, 62961-62969.

11. Matthews, G. Celestial body irradiance determination from an underfilled satellite radiometer: Application to albedo and thermal emission measurements of the moon using CEREs. Appl. Opt. 2008, 47, 4981-4993. [CrossRef] [PubMed]

12. Cao, C.Y.; Vermote, E.; Xiong, X.X. Using AVHRR lunar observations for NDVI long-term climate change detection. J. Geophys. Res. Atmos. 2009, 114. [CrossRef]

13. Eplee, R.E.; Sun, J.Q.; Meister, G.; Patt, F.S.; Xiong, X.X.; McClain, C.R. Cross calibration of SeaWiFS and MODIS using on-orbit observations of the moon. Appl. Opt. 2011, 50, 120-133. [CrossRef] [PubMed]

14. Uprety, S.; Cao, C.Y. Radiometric and spectral characterization and comparison of the Antarctic Dome C and Sonoran Desert sites for the calibration and validation of visible and near-infrared radiometers. J. Appl. Remote Sens. 2012, 6, 063541.

15. Doelling, D.R.; Morstad, D.; Scarino, B.R.; Bhatt, R.; Gopalan, A. The characterization of deep convective clouds as an invariant calibration target and as a visible calibration technique. IEEE Trans. Geosci. Remote Sens. 2013, 51, 1147-1159. [CrossRef]

16. Wielicki, B.A.; Young, D.F.; Mlynczak, M.G.; Thome, K.J.; Leroy, S.; Corliss, J.; Anderson, J.G.; Ao, C.O.; Bantges, R.; Best, F.; et al. Achieving climate change absolute accuracy in orbit. Bull. Am. Meteorol. Soc. 2013, 94, 1519-1539. [CrossRef]

17. Pearlman, A.; Datla, R.; Kacker, R.; Cao, C.Y. Translating radiometric requirements for satellite sensors to match international standards. J. Res. Natl. Inst. Stand. 2014, 119, 272-276. [CrossRef] [PubMed]

18. Weng, F.Z.; Yang, H. Validation of ATMS calibration accuracy using Suomi NPP pitch maneuver observations. Remote Sens. 2016. accepted.

19. Knapp, K.R.; Ansari, S.; Bain, C.L.; Bourassa, M.A.; Dickinson, M.J.; Funk, C.; Helms, C.N.; Hennon, C.C.; Holmes, C.D.; Huffman, G.J.; et al. Globally gridded satellite observations for climate studies. Bull. Am. Meteorol. Soc. 2011, 92, 893-907. [CrossRef]

20. Bates, J.J.; Privette, J.L. A maturity model for assessing the completeness of climate data records. EOS Trans. Am. Geophys. Union 2012, 93, 441. [CrossRef]

21. Huffman, G.J.; Adler, R.F.; Rudolf, B.; Schneider, U.; Keehn, P.R. Global precipitation estimates based on a technique for combining satellite-based estimates, rain-gauge analysis, and NWP model precipitation information. J. Clim. 1995, 8, 1284-1295. [CrossRef]

22. Ashouri, H.; Hsu, K.L.; Sorooshian, S.; Braithwaite, D.K.; Knapp, K.R.; Cecil, L.D.; Nelson, B.R.; Prat, O.P. Persiann-CDR daily precipitation climate data record from multisatellite observations for hydrological and climate studies. Bull. Am. Meteorol. Soc. 2015, 96, 69-83. [CrossRef]

23. Reynolds, R.W.; Smith, T.M.; Liu, C.; Chelton, D.B.; Casey, K.S.; Schlax, M.G. Daily high-resolution-blended analyses for sea surface temperature. J. Clim. 2007, 20, 5473-5496. [CrossRef] 
24. Walther, A.; Heidinger, A.K. Implementation of the daytime cloud optical and microphysical properties algorithm (Dcomp) in PATMOS-x. J. Appl. Meteorol. Clim. 2012, 51, 1371-1390. [CrossRef]

25. Heidinger, A.; Foster, M.; Botambekov, D.; Hiley, M.; Li, Y.; Walther, A. Using the NASA EOS a-train to probe the performance of the NOAA PATMOS-x cloud fraction CDR. Remote Sens. 2016. submitted.

26. Schreck, C.J.; Cordeira, J.M.; Margolin, D. Which MJO events affect North American temperatures? Mon. Weather Rev. 2013, 141, 3840-3850. [CrossRef]

27. Schreck, C.J.; Shi, L.; Kossin, J.P.; Bates, J.J. Identifying the MJO, equatorial waves, and their impacts using 32 years of HIRS upper-tropospheric water vapor. J. Clim. 2013, 26, 1418-1431. [CrossRef]

28. Sherbinin, A.D.; Levy, M.A.; Zell, E.; Weber, S.; Jaiteh, M. Using satellite data to develop environmental indicators. Environ. Res. Lett. 2014, 9, 084013. [CrossRef]

29. Schreck, C.J.; Bennett, S.; Cordeira, J.M.; Crouch, J.; Dissen, J.; Lang, A.L.; Margolin, D.; O'Shay, A.; Rennie, J.; Schneider, T.I.; et al. Natural gas prices and the extreme winters of 2011/12 and 2013/14 causes, indicators, and interactions. Bull. Am. Meteorol. Soc. 2015, 96, 1879-1894. [CrossRef]

30. Heidinger, A.K.; Straka, W.C.; Molling, C.C.; Sullivan, J.T.; Wu, X.Q. Deriving an inter-sensor consistent calibration for the AVHRR solar reflectance data record. Int. J. Remote Sens. 2010, 31, 6493-6517. [CrossRef]

31. Heidinger, A.K.; Evan, A.T.; Foster, M.J. A Naive Bayesian cloud-detection scheme derived from CALIPSO and applied within PATMOS-x. J. Appl. Meteorol. Climatol. 2012. [CrossRef]

32. Heidinger, A.K.; Foster, M.J.; Walther, A.; Zhao, X.-P. The pathfinder atmospheres-extended AVHRR climate dataset. Bull. Am. Meteorol. Soc. 2014, 95, 909-922. [CrossRef]

33. Zhao, X.-P.; Dubovik, O.; Smirnov, A.; Holben, B.N.; Sapper, J.; Pietras, C.; Voss, K.J.; Frouin, R. Regional evaluation of an advanced very high resolution radiometer (AVHRR) two-channel aerosol retrieval algorithm. J. Geophys. Res. 2004, 109, D02204. [CrossRef]

34. Zhao, T.X.; Chan, P.K.; Heidinger, A.K. A global survey of the effect of cloud contamination on the aerosol optical thickness and its long-term trend derived from operational AVHRR satellite observations. J. Geophys. Res. Atmos. 2013, 118, 2849-2857. [CrossRef]

35. WGClimate. Available online: http://ceos.org/ourwork/workinggroups/climate (accessed on 8 April 2016).

36. SCOPE-CM. Available online: http://www.scope-cm.org (accessed on 8 April 2016).

37. CDRP. Available online: http://www.ncdc.noaa.gov/cdr (accessed on 8 April 2016).

38. Zou, C.Z.; Wang, W.H. Intersatellite calibration of AMSU-A observations for weather and climate applications. J. Geophys. Res. Atmos. 2011, 116. [CrossRef]

39. Zou, C.Z.; Goldberg, M.D.; Cheng, Z.H.; Grody, N.C.; Sullivan, J.T.; Cao, C.Y.; Tarpley, D. Recalibration of microwave sounding unit for climate studies using simultaneous nadir overpasses. J. Geophys. Res. Atmos. 2006, 111. [CrossRef]

40. Santer, B.D.; Painter, J.F.; Mears, C.A.; Doutriaux, C.; Caldwell, P.; Arblaster, J.M.; Cameron-Smith, P.J.; Gillett, N.P.; Gleckler, P.J.; Lanzante, J.; et al. Identifying human influences on atmospheric temperature. Proc. Natl. Acad. Sci. USA 2013, 110, 26-33. [CrossRef] [PubMed]

41. Foster, M.J.; Heidinger, A. Entering the era of +30 -year satellite cloud climatologies: A North American case study. J. Clim. 2014, 27, 6687-6697. [CrossRef]

42. Bain, C.L.; De Paz, J.; Kramer, J.; Magnusdottir, G.; Smyth, P.; Stern, H.; Wang, C.C. Detecting the ITCZ in instantaneous satellite data using spatiotemporal statistical modeling: ITCZ climatology in the East Pacific. J. Clim. 2011, 24, 216-230. [CrossRef]

43. Shi, L.; Bates, J.J. Three decades of intersatellite-calibrated high-resolution infrared radiation sounder upper tropospheric water vapor. J. Geophys. Res. Atmos. 2011, 116. [CrossRef]

44. Chung, E.S.; Soden, B.; Sohn, B.J.; Shi, L. Upper-tropospheric moistening in response to anthropogenic warming. Proc. Natl. Acad. Sci. USA 2014, 111, 11636-11641. [CrossRef] [PubMed]

45. FIDUCEO. Available online: http://www.fiduceo.eu/ (accessed on 8 April 2016).

46. Berg, W.; Sapiano, M.R.P.; Horsman, J.; Kummerow, C. Improved geolocation and earth incidence angle information for a fundamental climate data record of the SSM/I sensors. IEEE Trans. Geosci. Remote Sens. 2013, 51, 1504-1513. [CrossRef]

47. Sapiano, M.R.P.; Berg, W.K.; McKague, D.S.; Kummerow, C.D. Toward an intercalibrated fundamental climate data record of the SSM/I sensors. IEEE Trans. Geosci. Remote Sens. 2013, 51, 1492-1503. [CrossRef]

48. Hilburn, K.A.; Wentz, F.J. Intercalibrated passive microwave rain products from the unified microwave ocean retrieval algorithm (UMORA). J. Appl. Meteorol. Clim. 2008, 47, 778-794. [CrossRef] 
49. Allan, R.P.; Soden, B.J. Atmospheric warming and the amplification of precipitation extremes. Science 2008, 321, 1481-1484. [CrossRef] [PubMed]

50. Miao, C.Y.; Ashouri, H.; Hsu, K.L.; Sorooshian, S.; Duan, Q.Y. Evaluation of the Persiann-CDR daily rainfall estimates in capturing the behavior of extreme precipitation events over China. J. Hydrometeorol. 2015, 16, 1387-1396. [CrossRef]

51. Zhao, X.-P. Satellite observed aerosol optical thickness and trend around megacities in the coastal zone. Adv. Meteorol. 2015, 2015, 170672. [CrossRef]

52. Sun, B.M.; Free, M.; Yoo, H.L.; Foster, M.J.; Heidinger, A.; Karlsson, K.G. Variability and trends in U.S. Cloud cover: ISCCP, PATMOS- $x$, and CLARA-A1 compared to homogeneity-adjusted weather observations. J. Clim. 2015, 28, 4373-4389. [CrossRef]

53. Klein, S.A.; McCoy, R.B.; Morrison, H.; Ackerman, A.S.; Avramov, A.; de Boer, G.; Chen, M.X.; Cole, J.N.S.; Del Genio, A.D.; Falk, M.; et al. Intercomparison of model simulations of mixed-phase clouds observed during the arm mixed-phase arctic cloud experiment. I: Single-layer cloud. Q. J. R. Meteorol. Soc. 2009, 135, 979-1002. [CrossRef]

54. Nielsen, J.K.; Foster, M.; Heidinger, A. Tropical stratospheric cloud climatology from the PATMOS-x dataset: An assessment of convective contributions to stratospheric water. Geophys Res Lett 2011, 38. [CrossRef]

55. Mecikalski, J.R.; Feltz, W.F.; Murray, J.J.; Johnson, D.B.; Bedka, K.M.; Bedka, S.T.; Wimmers, A.J.; Pavolonis, M.; Berendies, T.A.; Haggerty, J.; et al. Aviation applications for satellite-based observations of cloud properties, convection initiation, in-flight icing, turbulence, and volcanic ash. Bull. Am. Meteorol. Soc. 2007, 88, 1589-1607. [CrossRef]

56. Clayson, C.A.; Curry, J.A. Determination of surface turbulent fluxes for the tropical ocean-global atmosphere coupled ocean-atmosphere response experiment: Comparison of satellite retrievals and in situ measurements. J. Geophys. Res. Oceans 1996, 101, 28515-28528. [CrossRef]

57. Rodell, M.; Beaudoing, H.K.; L'Ecuyer, T.S.; Olson, W.S.; Famiglietti, J.S.; Houser, P.R.; Adler, R.; Bosilovich, M.G.; Clayson, C.A.; Chambers, D.; et al. The observed state of the water cycle in the early twenty-first century. J. Clim. 2015, 28, 8289-8318. [CrossRef]

58. L'Ecuyer, T.S.; Beaudoing, H.K.; Rodell, M.; Olson, W.; Lin, B.; Kato, S.; Clayson, C.A.; Wood, E.; Sheffield, J.; Adler, R.; et al. The observed state of the energy budget in the early twenty-first century. J. Clim. 2015, 28, 8319-8346. [CrossRef]

59. Lee, H.T.; Gruber, A.; Ellingson, R.G.; Laszlo, I. Development of the HIRS outgoing longwave radiation climate dataset. J. Atmos. Ocean. Technol. 2007, 24, 2029-2047. [CrossRef]

60. NSIDC. Available online: http://nsidc.org/data/G02202/versions/1 (accessed on 8 April 2016).

61. Donlon, C.; Robinson, I.; Casey, K.S.; Vazquez-Cuervo, J.; Armstrong, E.; Arino, O.; Gentemann, C.; May, D.; LeBorgne, P.; Piolle, J.; et al. The global ocean data assimilation experiment high-resolution sea surface temperature pilot project. Bull. Am. Meteorol. Soc. 2007, 88, 1197-1213. [CrossRef]

62. Pedelty, J.; Devadiga, S.; Masuoka, E.; Brown, M.; Pinzon, J.; Tucker, C.; Roy, D.P.; Ju, J.J.; Vermote, E.; Prince, S.; et al. Generating a long-term land data record from the AVHRR and MODIS instruments. In Proceedings of the IEEE International Geoscience and Remote Sensing Symposium, Barcelona, Spain, 23-27 July 2007.

63. Zhou, L.; Tian, Y.; Myneni, R.B.; Ciais, P.; Saatchi, S.; Liu, Y.Y.; Piao, S.; Chen, H.; Vermote, E.F.; Song, C.; et al. Widespread decline of Congo rainforest greenness in the past decade. Nature 2014, 509, 86-90. [CrossRef] [PubMed]

64. Morton, D.C.; Nagol, J.; Carabajal, C.C.; Rosette, J.; Palace, M.; Cook, B.D.; Vermote, E.F.; Harding, D.J.; North, P.R.J. Amazon forests maintain consistent canopy structure and greenness during the dry season. Nature 2014, 506, 221-224. [CrossRef] [PubMed]

65. Brown, R.D.; Robinson, D.A. Northern hemisphere spring snow cover variability and change over 1922-2010 including an assessment of uncertainty. Cryosphere 2011, 5, 219-229. [CrossRef]

66. Foster, J.L.; Cohen, J.; Robinson, D.A.; Estilow, T.W. A look at the date of snowmelt and correlations with the arctic oscillation. Ann. Glaciol. 2013, 54, 196-204. [CrossRef]

67. Mioduszewski, J.R.; Rennermalm, A.K.; Robinson, D.A.; Mote, T.L. Attribution of snowmelt onset in Northern Canada. J. Geophys. Res. Atmos. 2014, 119, 9638-9653. [CrossRef]

68. CCI. Available online: http://cci.esa.int/ (accessed on 6 April 2016). 
69. Popp, T.; de Leeuw, G.; Bingen, C.; Bruhl, C.; Capelle, V.; Chedin, A.; Clarisse, L.; Dubovik, O.; Griesfeller, J.; Heckel, A.; et al. Development, production and evaluation of aerosol climate data records from European satellite observations (Aerosol_cci). Remote Sens. 2016. (accepted).

70. CCI-Aerosol. Available online: http://www.esa-aerosol-cci.org/ (accessed on 6 April 2016).

71. Holzer-Popp, T.; de Leeuw, G.; Griesfeller, J.; Martynenko, D.; Kluser, L.; Bevan, S.; Davies, W.; Ducos, F.; Deuze, J.L.; Graigner, R.G.; et al. Aerosol retrieval experiments in the ESA Aerosol_cci project. Atmos. Meas. Tech. 2013, 6, 1919-1957. [CrossRef]

72. De Leeuw, G.; Holzer-Popp, T.; Bevan, S.; Davies, W.H.; Descloitres, J.; Grainger, R.G.; Griesfeller, J.; Heckel, A.; Kinne, S.; Kluser, L.; et al. Evaluation of seven European aerosol optical depth retrieval algorithms for climate analysis. Remote Sens. Environ. 2015, 162, 295-315. [CrossRef]

73. CCI-GHG. Available online: http://www.esa-ghg-cci.org/ (accessed on 8 April 2016).

74. CCI-SST. Available online: http://www.esa-sst-cci.org/ (accessed on 8 April 2016).

75. CCI-OC. Available online: http://www.esa-oceancolour-cci.org/ (accessed on 8 April 2016).

76. CCI-SIC. Available online: http:/ /esa-cci.nersc.no/ (accessed on 8 April 2016).

77. CCI-SM. Available online: http://esa-cci.nersc.no/ (accessed on 8 April 2016).

78. CCI-LC. Available online: http://www.esa-landcover-cci.org/ (accessed on 8 April 2016).

79. CMSAF. Available online: http://www.cmsaf.eu/ (accessed on 8 April 2016).

80. FTH. Available online: http://wui.cmsaf.eu/safira/action/viewDoiDetails?acronym=FTH_METEOSAT_V001 (accessed on 8 April 2016).

81. John, V.O.; Soden, B.J. Temperature and humidity biases in global climate models and their impact on climate feedbacks. Geophys. Res. Lett. 2007, 34. [CrossRef]

82. HOAPS. Available online: http://www.hoaps.zmaw.de/ (accessed on 8 April 2016).

83. CLARA-A1. Available online: https://climatedataguide.ucar.edu/climate-data/clara-a1-cloud-propertiessurface-albedo-and-surface-radiation-products-based-avhrr (accessed on 8 April 2016).

84. SARAH. Available online: https://climatedataguide.ucar.edu/climate-data/surface-solar-radiation-data-setheliosat-sarah-edition-1 (accessed on 8 April 2016).

85. 3TIER. Available online: http:/ /www.3tier.com (accessed on 8 April 2016).

86. 3TIER-Solar. Available online: http://www.3tier.com/en/support/solar-prospecting-tools/what-solarprospecting-data-has-been-created/ (accessed on 8 April 2016).

87. Huld, T.; Muller, R.; Gambardella, A. A new solar radiation database for estimating PV performance in Europe and Africa. Sol. Energy 2012, 86, 1803-1815. [CrossRef]

88. Wu, B.F.; Meng, J.H.; Li, Q.Z.; Yan, N.N.; Du, X.; Zhang, M. Remote sensing-based global crop monitoring: Experiences with China's cropwatch system. Int. J. Digit. Earth 2014, 7, 113-137. [CrossRef]

89. Santos, A.M.P. Fisheries oceanography using satellite and airborne remote sensing methods: A review. Fish. Res. 2000, 49, 1-20. [CrossRef]

90. Klemas, V. Fisheries applications of remote sensing: An overview. Fish. Res. 2013, 148, 124-136. [CrossRef]

91. Nagne, A.D.; Gawali, B.W. Transportation network analysis by using remote sensing and GIS a review. Int. J. Eng. Res. Appl. 2013, 3, 70-76.

92. Johannessen, O.M.; Alexandrov, V.Y.; Frolov, I.Y.; Sandven, S.; Pettersson, L.H.; Bobylev, L.P.; Kloster, K.; Smirnov, V.G.; Mironov, Y.U.; Babich, N.G. Remote Sensing of Sea Ice in the Northern Sea Route Studies and Applications Afterword; Springer: Berlin, Germany, 2007; pp. 423-425.

93. Estilow, T.W.; Young, A.H.; Robinson, D.A. A long-term northern hemisphere snow cover extent data record for climate studies and monitoring. Earth Syst. Sci. Data 2015, 7, 137-142. [CrossRef]

94. Smith, K. Environmental Hazards Assessing Risk and Reducing Disasters, 6th ed.; Routledge: Abingdon, UK, 2013.

95. Mouillot, F.; Schultz, M.G.; Yue, C.; Cadule, P.; Tansey, K.; Ciais, P.; Chuvieco, E. Ten years of global burned area products from spaceborne remote sensing-A review: Analysis of user needs and recommendations for future developments. Int. J. Appl. Earth Obs. 2014, 26, 64-79. [CrossRef]

96. Bach, H.; Appel, F.; Fellah, K.; de Fraipont, P. Application of flood monitoring from satellite for insurance. In Proceedings of the International Geoscience and Remote Sensing Symposium (IGARSS), Seoul, Korea, 25-29 July 2005. 
97. Young, F.; Chandler, O.; Apan, A. Crop hail damage: Insurance loss assessment using remote sensing. In Proceedings of the Remote Sensing and Photogrammetry Society Conference, Aberdeen, UK, 7-10 September 2004.

98. Rojas, O.; Vrieling, A.; Rembold, F. Assessing drought probability for agricultural areas in Africa with coarse resolution remote sensing imagery. Remote Sens. Environ. 2011, 115, 343-352. [CrossRef]

99. Leeuw, J.D.; Vrieling, A.; Shee, A.; Atzberger, C.; Hadgu, K.M.; Biradar, C.M.; Keah, H.; Turvey, C. The potential and uptake of remote sensing in insurance: A review. Remote Sens. 2014, 6, 10888-10912. [CrossRef]

100. Precision Farming. Available online: http://earthobservatory.nasa.gov/Features/PrecisionFarming/ (accessed on 8 April 2016).

101. Hall, A.; Lamb, D.W.; Holzapfel, B.; Louis, J. Optical remote sensing applications in viticulture-A review. Aust. J. Grape Wine Res. 2002, 8, 36-47. [CrossRef]

102. Zarco-Tejada, P.J.; Berjon, A.; Lopez-Lozano, R.; Miller, J.R.; Martin, P.; Cachorro, V.; Gonzalez, M.R.; de Frutos, A. Assessing vineyard condition with hyperspectral indices: Leaf and canopy reflectance simulation in a row-structured discontinuous canopy. Remote Sens. Environ. 2005, 99, 271-287. [CrossRef]

103. Asrar, G. Theory and Applications of Optical Remote Sensing; John Wiley \& Sons: New York, NY, USA, 1989.

104. Huete, A.R.; Didan, K.; Shimabukuro, Y.E.; Ratana, P.; Saleska, S.R.; Hutyra, L.R.; Yang, W.Z.; Nemani, R.R.; Myneni, R. Amazon rainforests green-up with sunlight in dry season. Geophys. Res. Lett. 2006, 33. [CrossRef]

105. Myneni, R.B.; Yang, W.Z.; Nemani, R.R.; Huete, A.R.; Dickinson, R.E.; Knyazikhin, Y.; Didan, K.; Fu, R.; Juarez, R.I.N.; Saatchi, S.S.; et al. Large seasonal swings in leaf area of amazon rainforests. Proc. Natl. Acad. Sci. USA 2007, 104, 4820-4823. [CrossRef] [PubMed]

106. Hansen, M.C.; Potapov, P.V.; Moore, R.; Hancher, M.; Turubanova, S.A.; Tyukavina, A.; Thau, D.; Stehman, S.V.; Goetz, S.J.; Loveland, T.R.; et al. High-resolution global maps of 21st-century forest cover change. Science 2013, 342, 850-853. [CrossRef] [PubMed]

107. Ruddell, S.; Walsh, M.J.; Kanakasabai, M. Forest Carbon Trading and Marketing in the United States; Society of American Foresters: Bethesda, MD, USA, 2006.

108. Leblon, B. Forest wildfire hazard monitoring using remote sensing: A review. Remote Sens. Rev. 2001, 20, 1-43. [CrossRef]

109. Chassot, E.; Bonhommeau, S.; Reygondeau, G.; Nieto, K.; Polovina, J.J.; Huret, M.; Dulvy, N.K.; Demarcq, H. Satellite remote sensing for an ecosystem approach to fisheries management. ICES J. Mar. Sci. 2011, 68, 651-666. [CrossRef]

110. Stuart, V.; Platt, T.; Sathyendranath, S.; Pravin, P. Remote sensing and fisheries: An introduction. ICES J. Mar. Sci. 2011, 68, 639-641. [CrossRef]

111. Stuart, V.; Platt, T.; Sathyendranath, S. The future of fisheries science in management: A remote-sensing perspective. ICES J. Mar. Sci. 2011, 68, 644-650. [CrossRef]

112. Laurs, R.M.; Fiedler, P.C.; Montgomery, D.R. Albacore tuna catch distributions relative to environmental features observed from satellites. Deep Sea Res. 1984, 31, 1085-1099. [CrossRef]

113. Straka, W.C.; Seaman, C.J.; Baugh, K.; Cole, K.; Stevens, E.; Miller, S.D. Utilization of the Suomi national polar-orbiting partnership (NPP) visible infrared imaging radiometer suite (VIIRS) day/night band for Arctic ship tracking and fisheries management. Remote Sens. 2015, 7, 971-989. [CrossRef]

114. Goodman, J.A.; Samuel, J.P.; Stuart, R.P. Coral Reef Remote Sensing; Springer: Berlin, Germany, 2013.

115. Tooke, T.R.; Coops, N.C. A review of remote sensing for urban energy system management and planning. In Proceedings of the Joint Urban Remote Sensing Event (JURSE), Sao Paulo, Brazil, 21-23 April 2013.

116. GST-Report. Available online: https://www.cicsnc.org/assets/pdfs/events/energy-sector-resilience/ Acclimatise_NCEI_Jan8.pdf (accessed on 6 April 2016).

117. Kazmi, S.J.H.; Usery, E.L. Application of remote sensing and GIS for the monitoring of diseases: A unique research agenda for geographers. Remote Sens. Rev. 2001, 20, 26. [CrossRef]

118. Hayes, R.O.; Maxwell, E.L.; Mitchell, C.J.; Woodzick, T.L. Detection, identification, and classification of mosquito larval habitats using remote-sensing scanners in earth-orbiting satellites. Bull. World Health Organ. 1985, 63, 361-374. [PubMed]

119. Martin, R.V. Satellite remote sensing of surface air quality. Atmos. Environ. 2008, 42, 7823-7843. [CrossRef]

120. Hutchison, K.D. Applications of MODIS satellite data and products for monitoring air quality in the State of Texas. Atmos. Environ. 2003, 37, 2403-2412. [CrossRef] 
121. Ritchie, J.C.; Zimba, P.V.; Everitt, J.H. Remote sensing techniques to assess water quality. Photogramm. Eng. Remote Sens. 2003, 69, 695-704. [CrossRef]

122. Alsdorf, D.E.; Rodriguez, E.; Lettenmaier, D.P. Measuring surface water from space. Rev. Geophys. 2007, 45. [CrossRef]

123. Toll, D.; Doorn, B.; Engman, E. NASA'S water resources element within the applied sciences program. In Proceedings of the 2010 IEEE International Geoscience and Remote Sensing Symposium (IGARSS), Honolulu, HI, USA, 25-30 July 2010.

124. Kalma, J.D.; McVicar, T.R.; McCabe, M.F. Estimating land surface evaporation: A review of methods using remotely sensed surface temperature data. Surv. Geophys. 2008, 29, 421-469. [CrossRef]

125. Ralph, F.M.; Neiman, P.J.; Wick, G.A.; Gutman, S.I.; Dettinger, M.D.; Cayan, D.R.; White, A.B. Flooding on California's Russian river: Role of atmospheric rivers. Geophys. Res. Lett. 2006, 33. [CrossRef]

126. Stephens, G.L.; Kummerow, C.D. The remote sensing of clouds and precipitation from space: A review. J. Atmos. Sci. 2007, 64, 3742-3765. [CrossRef]

127. Alley, W.M.; Healy, R.W.; LaBaugh, J.W.; Reilly, T.E. Hydrology—Flow and storage in groundwater systems. Science 2002, 296, 1985-1990. [CrossRef] [PubMed]

128. Wagner, W.; Bloschl, G.; Pampaloni, P.; Calvet, J.C.; Bizzarri, B.; Wigneron, J.P.; Kerr, Y. Operational readiness of microwave remote sensing of soil moisture for hydrologic applications. Nordrol. Hydrol. 2007, 38, 1-20. [CrossRef]

129. Casse, C.; Gosset, M. Analysis of hydrological changes and flood increase in Niamey based on the PERSIANN-CDR satellite rainfall estimate and hydrological simulations over the 1983-2013 period. Proc. IAHS 2015, 370, 117-123. [CrossRef]

130. Luchetti, N.T.; Sutton, J.R.P.; Wright, E.E.; Kruk, M.C.; Marra, J.J. When El Niño rages: How satellite data can help water-stressed islands. Bull. Am. Meteorol. Soc. 2016. [CrossRef]

131. World Disasters Report, International Federation of Red Cross and Red Crescent Societies; Imprimerie Chirat: Lyons, France, 2012.

132. Wu, H.; Adler, R.F.; Tian, Y.D.; Huffman, G.J.; Li, H.Y.; Wang, J.J. Real-time global flood estimation using satellite-based precipitation and a coupled land surface and routing model. Water Resour. Res. 2014, 50, 2693-2717. [CrossRef]

133. NASA-ASP. Available online: https://c3.nasa.gov/water/projects/ (accessed on 8 April 2016).

134. U.S. Department of transportation. Remote sensing for transportation: Products and results: Foundations for the future. Proceedings of Committee for Conferences on Remote Sensing and Spatial Information Technologies for Transportation.

135. Jensen, J.R.; Cowen, D.C. Remote sensing of urban suburban infrastructure and socio-economic attributes. Photogramm. Eng. Remote Sens. 1999, 65, 611-622.

136. Bahaire, T.; Elliott-White, M. The application of geographical information systems (GIS) in sustainable tourism planning: A review. J. Sustain. Tour. 1999, 7, 159-174. [CrossRef]

137. Levy, R.M.; Dickson, E.E. GIS, remote sensing, and tourism destination management. In Community Destination Management in Developing Economies; The Haworth Hospitality Press: New York, NY, USA, 2006; pp. 101-112.

138. National Oceanic and Atmospheric Administration. NOAA'S Next Generation Strategic Plan; National Oceanic and Atmospheric Administration: Silver Spring, MD, USA, 2010.

139. Gössling, S.; Peeters, P.; Hall, C.M.; Ceron, J.P.; Dubois, G.; Scott, D. Tourism and water use: Supply, demand, and security. Tourism Management 2012, 33, 1-15. [CrossRef]

140. Nagendra, H.; Tucker, C.; Carlson, L.; Southworth, J.; Karmacharya, M.; Karna, B. Monitoring parks through remote sensing: Studies in Nepal and Honduras. Environ. Manag. 2004, 34, 748-760. [CrossRef] [PubMed]

141. Southworth, J.; Nagendra, H.; Munroe, D.K. Introduction to the special issue: Are parks working? Exploring human-environment tradeoffs in protected area sonservation. Appl. Geogr. 2006, 26, 87-95. [CrossRef]

142. Zhang, X.Y.; Goldberg, M.D. Monitoring fall foliage coloration dynamics using time-series satellite data. Remote Sens. Environ. 2011, 115, 382-391. [CrossRef]

143. Saha, S.; Moorthi, S.; Pan, H.L.; Wu, X.R.; Wang, J.D.; Nadiga, S.; Tripp, P.; Kistler, R.; Woollen, J.; Behringer, D.; et al. The NCEP climate forecast system reanalysis. Bull. Am. Meteorol. Soc. 2010, 91, 1015-1057. [CrossRef] 
144. Dee, D.P.; Uppala, S.M.; Simmons, A.J.; Berrisford, P.; Poli, P.; Kobayashi, S.; Andrae, U.; Balmaseda, M.A.; Balsamo, G.; Bauer, P.; et al. The era-interim reanalysis: Configuration and performance of the data assimilation system. Q. J. R. Meteorol. Soc. 2011, 137, 553-597. [CrossRef]

145. Rienecker, M.M.; Suarez, M.J.; Gelaro, R.; Todling, R.; Bacmeister, J.; Liu, E.; Bosilovich, M.G.; Schubert, S.D.; Takacs, L.; Kim, G.K.; et al. MERRA: NASA'S modern-era retrospective analysis for research and applications. J. Clim. 2011, 24, 3624-3648. [CrossRef]

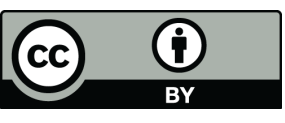

(C) 2016 by the authors; licensee MDPI, Basel, Switzerland. This article is an open access article distributed under the terms and conditions of the Creative Commons by Attribution (CC-BY) license (http://creativecommons.org/licenses/by/4.0/). 